\title{
The structural complexity of the Gammaproteobacteria flagellar motor is related to the type of its torque-generating stators
}

\author{
Mohammed Kaplan ${ }^{1}$, Debnath Ghosal ${ }^{1}$, Poorna Subramanian ${ }^{1}$, Catherine M. Oikonomou ${ }^{1}$, Andreas Kjær ${ }^{*}$, Sahand \\ Pirbadian $^{2}$, Davi R. Ortega ${ }^{1}$, Mohamed Y. El-Naggar ${ }^{2}$ and Grant J. Jensen ${ }^{1,3,4}$ \\ ${ }^{1}$ Division of Biology and Biological Engineering, California Institute of Technology, Pasadena, CA 91125. \\ ${ }^{2}$ Department of Physics and Astronomy, Biological Sciences, and Chemistry, University of Southern California, Los \\ Angeles, CA 90089. \\ ${ }^{3}$ Howard Hughes Medical Institute, California Institute of Technology, Pasadena, CA 91125. \\ *Present address: Rex Richards Building, South Parks Road, Oxford OX1 3QU \\ ${ }^{4}$ Corresponding author: jensen@,caltech.edu.
}

\begin{abstract}
:
The bacterial flagellar motor is a cell-envelope-embedded macromolecular machine that functions as a propeller to move the cell. Rather than being an invariant machine, the flagellar motor exhibits significant variability between species, allowing bacteria to adapt to, and thrive in, a wide range of environments. For instance, different torquegenerating stator modules allow motors to operate in conditions with different $\mathrm{pH}$ and sodium concentrations and some motors are adapted to drive motility in high-viscosity environments. How such diversity evolved is unknown. Here we use electron cryo-tomography to determine the in situ macromolecular structures of the flagellar motors of three Gammaproteobacteria species: Legionella pneumophila, Pseudomonas aeruginosa, and Shewanella oneidensis MR-1, providing the first views of intact motors with dual stator systems. Complementing our imaging with bioinformatics analysis, we find a correlation between the stator system of the motor and its structural complexity. Motors with a single $\mathrm{H}^{+}$-driven stator system have only the core P- and L-rings in their periplasm; those with dual $\mathrm{H}^{+}$-driven stator systems have an extra component elaborating their P-ring; and motors with $\mathrm{Na}^{+}-\left(\right.$or dual $\left.\mathrm{Na}^{+}-\mathrm{H}^{+}\right)$driven stator systems have additional rings surrounding both their P- and L-rings. Our results suggest an evolution of structural complexity that may have enabled pathogenic bacteria like L. pneumophila and P. aeruginosa to colonize higher-viscosity environments in animal hosts.
\end{abstract}




\section{Introduction}

30 The bacterial flagellum is a macromolecular machine that transforms the movement of ions $\left(\mathrm{H}^{+}\right.$or $\left.\mathrm{Na}^{+}\right)$across the

31 cell membrane into a mechanical torque to move the bacterial cell through its environment[1]. In general, the

32 flagellum consists of a cell-envelope-embedded motor, a hook which acts as a universal joint and a long propeller-

33 like filament[2,3]. The motor can rotate the filament in either a counterclockwise or clockwise direction. For cells

34 with a single flagellum this drives the cell forward or backward; for peritrichous cells this results in "run" or

35 "tumble" movements. Flagella can also exhibit more complex behavior; it was recently reported that the Shewanella

36 putrefaciens flagellum can wrap around the cell to mediate a screw-like motion that allows the cell to escape narrow

37 traps[4]. Besides their role in motility, bacterial flagella participate in other vital activities of the cell such as biofilm

38 formation[5]. Moreover, the virulence of many human pathogens depends directly on their flagella, with flagellated

strains of Pseudomonas aeruginosa and Legionella pneumophila causing more serious infections with higher mortality rates[6,7]. P. aeruginosa lacking fully-assembled flagella cause no mortality and are $75 \%$ less likely to

41 cause pneumonia in mice[6].

43 The best-studied flagellar motor, in Salmonella enterica, consists of several sub-complexes, which we will describe

44 in order from the inside out. On the cytoplasmic side are the inner-membrane-embedded MS ring (formed by the protein FliF) and the C-ring (aka the switch complex, formed by FliN, FliM and FliG). The C-ring encircles a type III secretion system (T3SS) export apparatus (FliH, FliI, FliJ, FlhA, FlhB, FliP, FliQ and FliR). Spanning the space

47 from the inner membrane to the peptidoglycan cell wall is the ion channel (called the stator), a complex of two proteins (MotA and MotB) with 4:2 stoichiometry[8,9]. The interaction between the stator and the C-ring (FliG) generates the torque required to drive the flagellum. The MS ring is coupled to the extracellular hook (FlgE) through the rod (FlgB, FlgC, FlgF and FlgG). The rod is further surrounded by two other rings: the P- (peptidoglycan, FlgI)

51 and the L- (lipopolysaccharide, FlgH) rings which act as bushings during rod rotation. Extending from the hook is 52 the filament (FliC) which is many micrometers in length. In addition to these components, the assembly of the 53 whole flagellar motor is a highly synchronized process that requires a plethora of additional chaperones and capping 54 proteins[10-12]. 
56 Recently, the development of electron cryo-tomography (ECT)[13,14] has allowed the determination of the

57 complete structures of flagellar motors in their cellular milieu at macromolecular $(\sim 5 \mathrm{~nm})$ resolution. ECT studies

58 of many different bacterial species have revealed that while the core structure described above is conserved, the

59 flagellar motor has evolved many species-specific adaptations to different environmental conditions[15-21]. For

60 example, extra periplasmic rings were found to elaborate the canonical P- and L-rings in the motor of the

61 Gammaproteobacteria Vibrio species. These rings are called the T-ring (MotX and $\mathrm{Y}$ ) and $\mathrm{H}$-ring (FlgO, $\mathrm{P}$ and

$62 \mathrm{~T})[20]$. Unlike the $S$. enterica motor described above, which is driven by $\mathrm{H}^{+}$ions, the motors of Vibrio and other

63 marine bacteria employ different stators (PomA and PomB) which utilize $\mathrm{Na}^{+}$. These $\mathrm{Na}^{+}$-dependent stators generate

64 higher torque $(\sim 2,200 \mathrm{pN})$ than $\mathrm{H}^{+}$-dependent stators $(\sim 1,200 \mathrm{pN})$, driving the motor at higher speeds (up to 1,700

$65 \mathrm{~Hz}$ compared to $\sim 300 \mathrm{~Hz}$ in $\mathrm{H}^{+}$-driven motors)[22].

67 Most flagellated bacteria use a single stator system - either $\mathrm{H}^{+}$-driven or $\mathrm{Na}^{+}$-driven, depending on their

68 environment. Some species, however, such as Vibrio alginolyticus, use two distinct types of motors to move in 69 different environments: a polar $\mathrm{Na}^{+}$-driven flagellum and lateral $\mathrm{H}^{+}$-driven flagella. Still other species employ dual stator systems with a single flagellar motor, conferring an advantage for bacteria that experience a range of 71 environments (see [23] and references therein). For example, P. aeruginosa employs a dual $\mathrm{H}^{+}$-driven stator system 72 (MotAB and MotCD). While the MotAB system is sufficient to move the cell in a liquid environment[24], MotCD 73 is necessary to allow the cell to move in more viscous conditions[25]. Shewanella oneidensis MR-1 combines both

$74 \mathrm{Na}^{+}$- and $\mathrm{H}^{+}$-dependent stators in a single motor, enabling the bacterium to move efficiently under conditions of 75 different $\mathrm{pH}$ and $\mathrm{Na}^{+}$concentration[26]. How these more elaborate motors may have evolved remains an open 76 question. Here, we used ECT to determine the first in situ structures of three Gammaproteobacteria flagellar motors with dual stator systems: in L. pneumophila, P. aeruginosa and S. oneidensis MR-1. L. pneumophila and P. aeruginosa have

80 dual $\mathrm{H}^{+}$-dependent stator systems and $S$. oneidensis has a dual $\mathrm{Na}^{+}-\mathrm{H}^{+}$-dependent stator. This imaging, along with 81 bioinformatics analysis, shows a correlation between the structural complexity of the motor and its stator system, suggesting a possible evolutionary pathway. 


\section{$84 \quad$ Results and Discussion}

85 To determine the structures of the flagellar motors of L. pneumophila, P. aeruginosa, and S. oneidensis we imaged 86 intact cells of each species in a hydrated frozen state using ECT. We identified clearly visible flagellar motors in the 87 tomographic reconstructions and performed sub-tomogram averaging to enhance the signal-to-noise ratio, 88 generating a 3D average of the motor of each species at macromolecular resolution (Fig. 1 and S1). While all three motors shared the conserved core structure of the flagellar motor, they exhibited different periplasmic decorations surrounding this conserved core. While the $S$. oneidensis and P. aeruginosa averages showed clear densities corresponding to the stators (Fig. $1 \mathrm{E}, \mathrm{F}, \mathrm{K}$ and L, orange density), none were visible in the L. pneumophila average, suggesting that they were more variable, or dynamic. Interestingly, we observed a novel feature in the $S$. oneidensis motor: an extra ring outside the outer membrane (Fig. 1 A-F, purple density). This structure is reminiscent of the Oring (outer membrane ring) described recently in the sheathed flagellum of Vibrio alginolyticus[17]. However, while the $V$. alginolyticus O-ring was associated with a $90^{\circ}$ bend in the outer membrane, no such outer membrane bend was seen in the unsheathed $S$. oneidensis flagellum, so the function of this structure remains mysterious.

The most striking difference between the three motor structures was the L- and P-rings, which were highly elaborated in S. oneidensis. The P. aeruginosa and L. pneumophila motors lacked additional rings associated with correlates with motor type, we compared our three new ECT structures with those of the five previously-published 
H-rings was suggested to be specific to the $\mathrm{Na}^{+}$-driven Vibrio motors[20] with the FlgT protein required for the formation of both rings[27].

Previous studies showed that MotX and MotY are important for flagellar rotation in S. oneidensis but it was not known whether they form part of the motor or not[28]. Similarly, bioinformatics analysis and biochemical studies showed that MotY is involved in the function of the P. aeruginosa motor, but the structural basis of this role was not known[24]. We therefore performed a bioinformatics search for candidate homologs of MotX, MotY, FlgO, FlgP and FlgT in the genomes of $P$. aeruginosa, L. pneumophila and S. oneidensis to examine whether there is a correlation between the presence of homologous genes and the extra periplasmic rings observed in the ECT

121 structures. While we found candidates for all five proteins constituting the T- and H-rings in S. oneidensis as 122 previously suggested[29], only MotY candidates were found in L. pneumophila and P. aeruginosa (Table S1). This 123 is in accordance with our ECT structures, which showed that L. pneumophila and P. aeruginosa motors have a ring 124 surrounding only their P-rings while the S. oneidensis motor has rings surrounding both the P- and L-rings. These 125 rings are likely T- and H-rings, respectively, as in Vibrio. The lack of candidate MotX homologs in the genomes of L. pneumophila and P. aeruginosa (Table S1) is consistent with their lack of PomB, the component of the $\mathrm{Na}^{+}-$

127 dependent stator with which MotX interacts. Interestingly, the absence of candidates for FlgT in the L. pneumophila 128 and P. aeruginosa genomes suggests that it may not be required for the recruitment of MotY as in Vibrio species.

To see whether these correlations hold more broadly, we expanded our bioinformatics analysis to additional species 131 of Gammaproteobacteria. We examined the genomes of species with single $\mathrm{H}^{+}$-driven stator systems (Table S2), dual $\mathrm{H}^{+}$-driven stator systems (Table S3) and $\mathrm{Na}^{+}$-driven stator systems (Table S4). Interestingly, we identified a second species, Colwellia psychrerythraea $34 \mathrm{H}$, with a single motor and candidates for both PomAB $\left(\mathrm{Na}^{+}-\right.$driven) 134 and MotAB ( $\mathrm{H}^{+}$-driven) stator systems, similar to S. oneidensis MR-1 (Table S5). In all species we examined, we observed the same pattern: (i) genomes of species with single $\mathrm{H}^{+}$-driven stator systems lacked homologs of H- or Tring components; (ii) genomes of species with $\mathrm{Na}^{+}$stator systems contained homologs of all $\mathrm{H}$ - and T-ring components, and (iii) genomes of species with dual $\mathrm{H}^{+}$-driven stator systems contained candidate homologs only for 
contained a homolog of FlgO in addition to MotY. None of the eight species with dual $\mathrm{H}^{+}$-driven stator systems we examined contained a homolog of FlgT, further suggesting that it is not essential for MotY stabilization in this group.

142 Together, our results from ECT imaging of flagellar motors in situ and bioinformatics analysis reveal a correlation

143 between the structural complexity of the flagellar motor of Gammaproteobacteria and the type of its torque-

144 generating unit, the stator (summarized in Fig. 3). Low-speed motors with single $\mathrm{H}^{+}$-stator systems have only the P-

145 and L-ring, while high-speed motors using $\mathrm{Na}^{+}$have two extra periplasmic rings, the $\mathrm{T}$ - and H-rings. Unexpectedly,

146 we find that motors with dual $\mathrm{H}^{+}$-driven stator systems represent a hybrid structure between the two, elaborating

147 their P-rings with one of the five components of the T- and H-rings, MotY. This extra MotY ring might help to

148 stabilize the motor under conditions of increased load, as in the viscous environment of the pulmonary system

149 encountered by L. pneumophila and P. aeruginosa. These results therefore suggest an evolutionary pathway in

150 which these pathogenic Gammaproteobacteria species could have borrowed a motor stabilization strategy from

151 related $\mathrm{Na}^{+}$-driven motors to allow them to colonize animal hosts.

\section{Acknowledgements:}

154 This work is supported by the National Institutes of Health (NIH, grant R01 AI127401 to G.J.J.). M.K. is supported 155 by a postdoctoral Rubicon fellowship from De Nederlandse Organisatie voor Wetenschappelijk Onderzoek (NWO).

156 S.P. and M.Y.E.-N. are supported by the Air Force Office of Scientific Research Presidential Early Career Award 157 for Scientists and Engineers (FA955014-1-0294, to M.Y.E.-N.). 


\section{References:}

164 1. Sowa Y, Berry RM (2008) Bacterial flagellar motor. Q Rev Biophys 41.

165 2. Berg HC (2003) The rotary motor of bacterial flagella. Annu Rev Biochem 72: 19-54.

166 3. Altegoer F, Bange G (2015) Undiscovered regions on the molecular landscape of flagellar assembly. Curr 167 Opin Microbiol 28: 98-105.

168 4. Kühn MJ, Schmidt FK, Eckhardt B, Thormann KM (2017) Bacteria exploit a polymorphic instability of the flagellar filament to escape from traps. Proc Natl Acad Sci 114: 6340-6345.

170 5. Belas R (2014) Biofilms, flagella, and mechanosensing of surfaces by bacteria. Trends Microbiol 22: 517-527.

171 6. Feldman M, Bryan R, Rajan S, Scheffler L, Brunnert S, Tang H, Prince A (1998) Role of flagella in 172 pathogenesis of Pseudomonas aeruginosa pulmonary infection. Infect Immun 66: 43-51.

173 7. Appelt S, Heuner K (2017) The flagellar regulon of Legionella-A Review. Front Cell Infect Microbiol 7:.

174 8. Koebnik R (1995) Proposal for a peptidoglycan-associating alpha-helical motif in the C-terminal regions of 175 some bacterial cell-surface proteins. Mol Microbiol 16: 1269-1270.

176 9. Morimoto Y, Minamino T (2014) Structure and function of the bi-directional bacterial flagellar motor. $177 \quad$ Biomolecules 4: 217-234.

178 10. Macnab RM (1999) The bacterial flagellum: reversible rotary propellor and type III export apparatus. $J$ Bacteriol 181: 7149-7153.

11. Evans LDB, Hughes C, Fraser GM (2014) Building a flagellum outside the bacterial cell. Trends Microbiol 22: $566-572$. MY, Jensen GJ (2018) Stable sub-complexes observed in situ suggest a modular assembly pathway of the bacterial flagellar motor. bioRxiv.

13. Oikonomou CM, Jensen GJ (2017) A new view into prokaryotic cell biology from electron cryotomography. Nat Rev Microbiol 15: 128.

14. Gan L, Jensen GJ (2012) Electron tomography of cells. Q Rev Biophys 45: 27-56. et al. (2011) Structural diversity of bacterial flagellar motors. EMBO J 30: 2972-2981. 
16. Beeby M, Ribardo DA, Brennan CA, Ruby EG, Jensen GJ, Hendrixson DR (2016) Diverse high-torque bacterial flagellar motors assemble wider stator rings using a conserved protein scaffold. Proc Natl Acad Sci 113: E1917-E1926.

17. Zhu S, Nishikino T, Hu B, Kojima S, Homma M, Liu J (2017) Molecular architecture of the sheathed polar flagellum in Vibrio alginolyticus. Proc Natl Acad Sci 201712489.

18. Zhao X, Norris SJ, Liu J (2014) Molecular architecture of the bacterial flagellar motor in cells. Biochemistry (Mosc) 53: 4323-4333.

19. Chaban B, Coleman I, Beeby M (2018) Evolution of higher torque in Campylobacter-type bacterial flagellar motors. Sci Rep 8:.

20. Minamino T, Imada K (2015) The bacterial flagellar motor and its structural diversity. Trends Microbiol 23: $267-274$.

21. Terashima H, Kawamoto A, Morimoto YV, Imada K, Minamino T (2017) Structural differences in the bacterial flagellar motor among bacterial species. Biophys Physicobiology 14: 191-198.

22. Magariyama Y, Sugiyama S, Muramoto K, Maekawa Y, Kawagishi I, Imae Y, Kudo S (1994) Very fast flagellar rotation. Nature 371: 752-752.

23. Thormann KM, Paulick A (2010) Tuning the flagellar motor. Microbiology 156: 1275-1283.

24. Doyle TB, Hawkins AC, McCarter LL (2004) The complex flagellar torque generator of Pseudomonas aeruginosa. J Bacteriol 186: 6341-6350.

25. Toutain CM, Caizza NC, Zegans ME, O'Toole GA (2007) Roles for flagellar stators in biofilm formation by Pseudomonas aeruginosa. Res Microbiol 158: 471-477. dynamics in the Shewanella oneidensis MR-1 flagellar motor: Shewanella oneidensis MR-1 flagellar motor. Mol Microbiol 96: 993-1001.

27. Terashima H, Li N, Sakuma M, Koike M, Kojima S, Homma M, Imada K (2013) Insight into the assembly mechanism in the supramolecular rings of the sodium-driven Vibrio flagellar motor from the structure of FlgT. Proc Natl Acad Sci 110: 6133-6138.

28. Koerdt A, Paulick A, Mock M, Jost K, Thormann KM (2009) MotX and MotY are required for flagellar rotation in Shewanella oneidensis MR-1. J Bacteriol 191: 5085-5093. 
29. Wu L, Wang J, Tang P, Chen H, Gao H (2011) Genetic and molecular characterization of flagellar assembly in Shewanella oneidensis. PLoS ONE 6: e21479.

30. Subramanian P, Pirbadian S, El-Naggar MY, Jensen GJ (2018) Ultrastructure of Shewanella oneidensis MR-1 nanowires revealed by electron cryotomography. Proc Natl Acad Sci 115: E3246-E3255. DA, Shi L, et al. (2014) Shewanella oneidensis MR-1 nanowires are outer membrane and periplasmic extensions of the extracellular electron transport components. Proc Natl Acad Sci 111: 12883-12888.

32. Myers CR, Nealson KH (1988) Bacterial manganese reduction and growth with manganese oxide as the sole electron acceptor. Science 240: 1319-1321.

33. Bouhenni RA, Vora GJ, Biffinger JC, Shirodkar S, Brockman K, Ray R, Wu P, Johnson BJ, Biddle EM, Marshall MJ, et al. (2010) The role of Shewanella oneidensis MR-1 outer surface structures in extracellular electron transfer. Electroanalysis 22: 856-864.

34. Charania MA, Brockman KL, Zhang Y, Banerjee A, Pinchuk GE, Fredrickson JK, Beliaev AS, Saffarini DA (2009) Involvement of a membrane-bound class III adenylate cyclase in regulation of anaerobic respiration in Shewanella oneidensis MR-1. J Bacteriol 191: 4298-4306. tomography: an integrated software suite for real-time electron microscopic tomographic data collection, alignment, and reconstruction. J Struct Biol 157: 138-147.

36. Kremer JR, Mastronarde DN, McIntosh JR (1996) Computer visualization of three-dimensional image data using IMOD. J Struct Biol 116: 71-76.

37. Agulleiro JI, Fernandez JJ (2011) Fast tomographic reconstruction on multicore computers. Bioinformatics 27: $582-583$. 
bioRxiv preprint first posted online Jul. 14, 2018; doi: http://dx.doi.org/10.1101/369397. The copyright holder for this preprint (which was not peer-reviewed) is the author/funder, who has granted bioRxiv a license to display the preprint in perpetuity. It is made available under a CC-BY-NC-ND 4.0 International license.

\section{$245 \quad$ Figure 1}

246

247

248

249

250

251
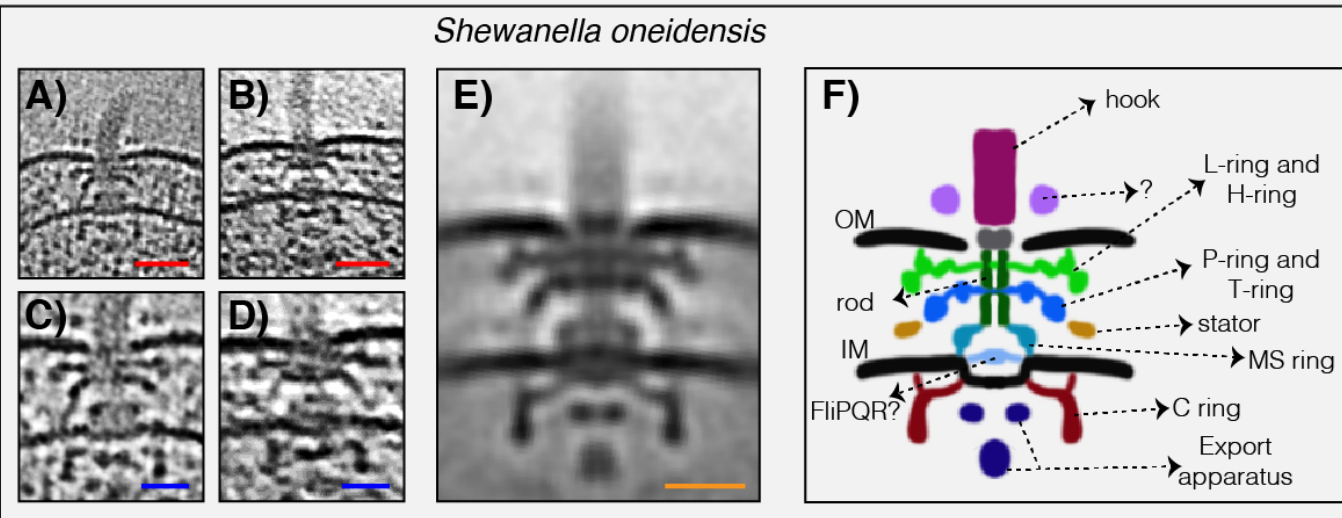

253

254

255

256

257

258

\section{Pseudomonas aeruginosa}

260
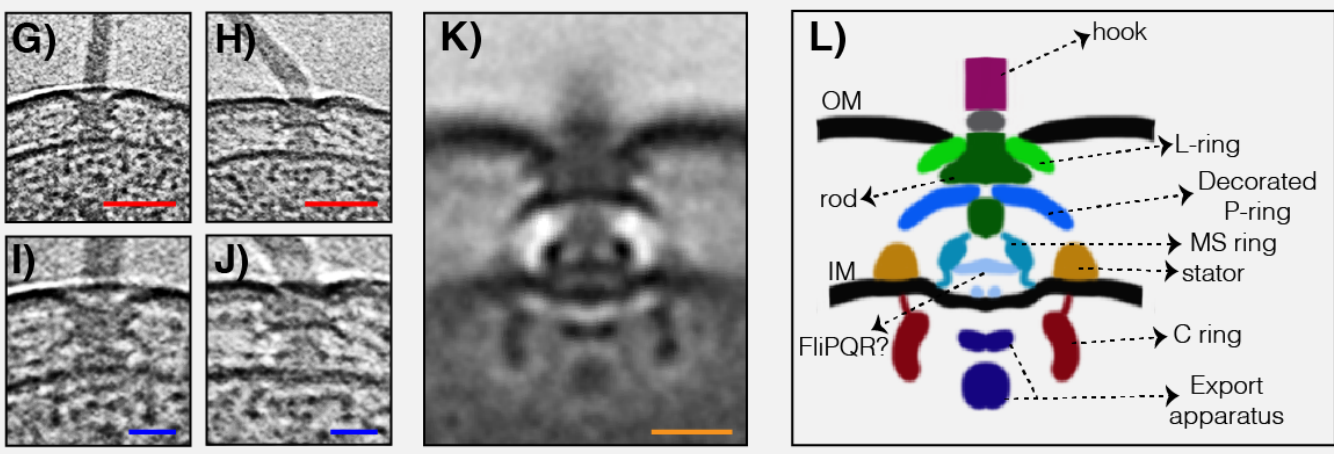

261

262

263

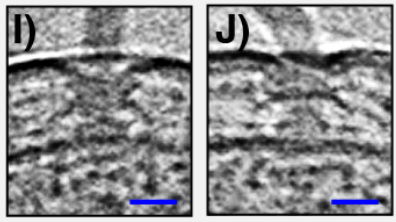

Legionella pneumophila

264

265

266

267

\section{Q)}
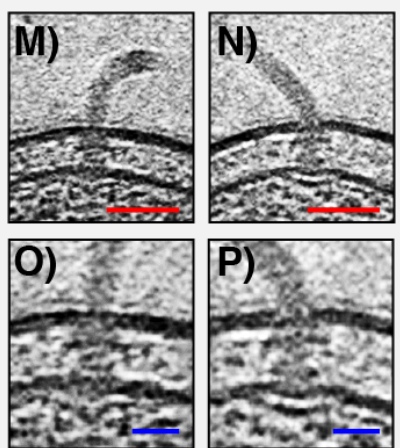

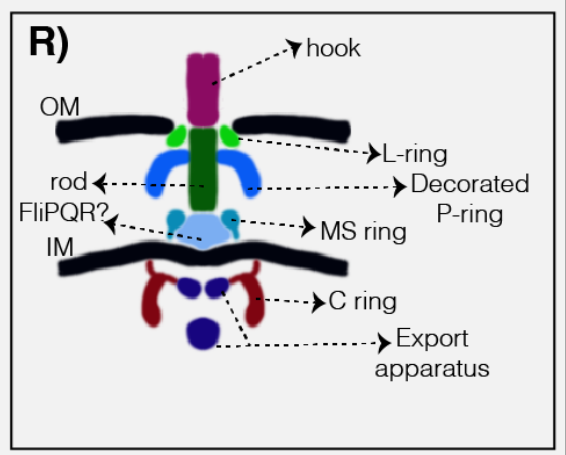


bioRxiv preprint first posted online Jul. 14 2018; doi: $h t t p / / d x$ doi org/10.1101/369397. The copyright holder for this preprint (which was not peer-reviewed) is the author/funder, who has granted bioRxiv a license to display the preprint in perpetuity. It is made available under a CC-BY-NC-ND 4.0 International license.

Figure 2

Gammaproteobacteria

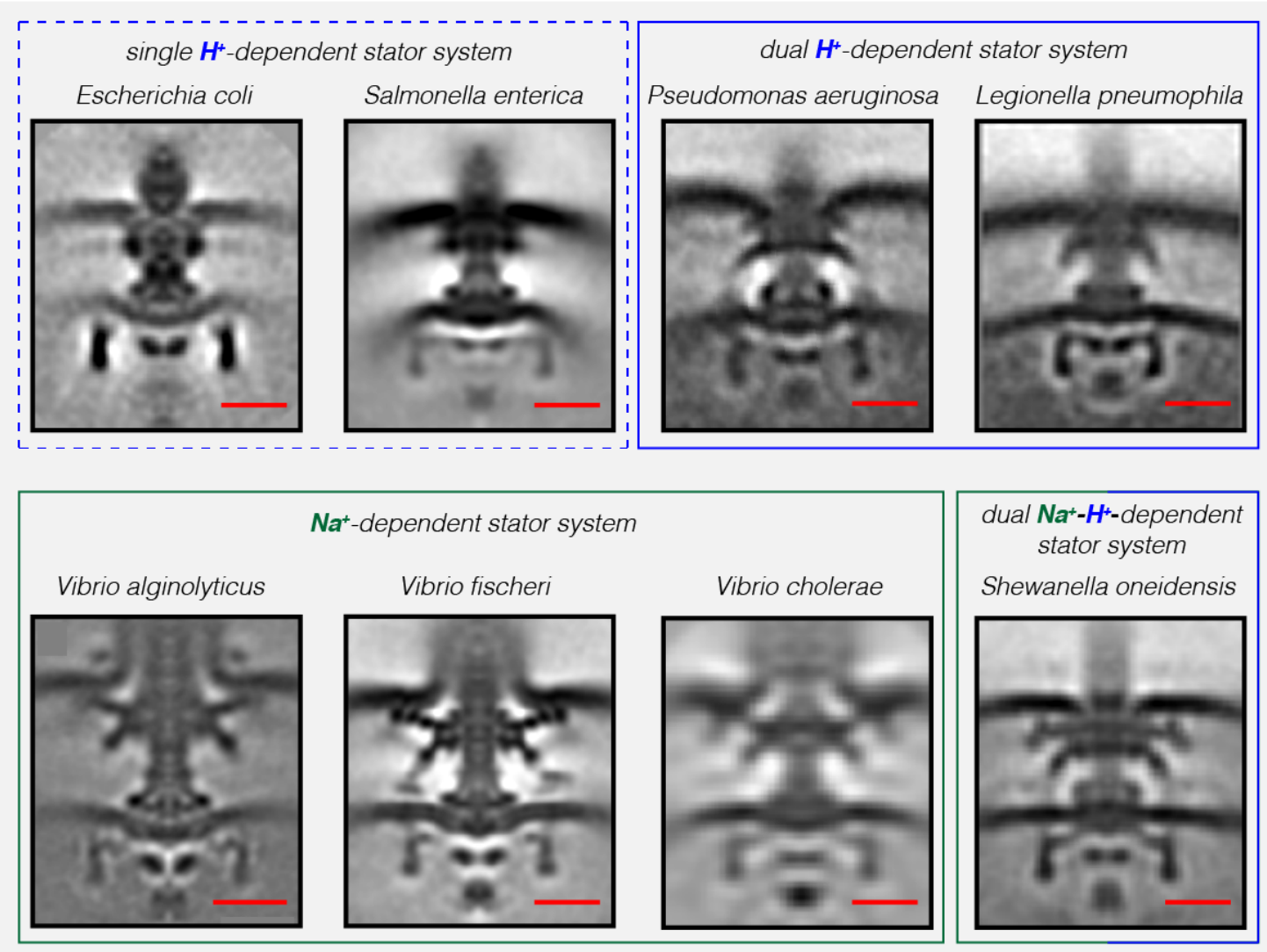


bioRxiv preprint first posted online Jul. 14 2018; doi: http//dx doi.org/10.1101/369397. The copyright holder for this preprint (which was not peer-reviewed) is the author/funder, who has granted bioRxiv a license to display the preprint in perpetuity. It is made available under a CC-BY-NC-ND 4.0 International license.

Figure 3

287

288

289

290

291

292

single $\boldsymbol{H}^{+}$-dependent stator

dual $\boldsymbol{H}^{+}$-dependent stator

dual $\mathrm{Na}^{+}-\mathrm{H}^{+}$-dependent stator (Salmonella) (Legionella) (Shewanella)
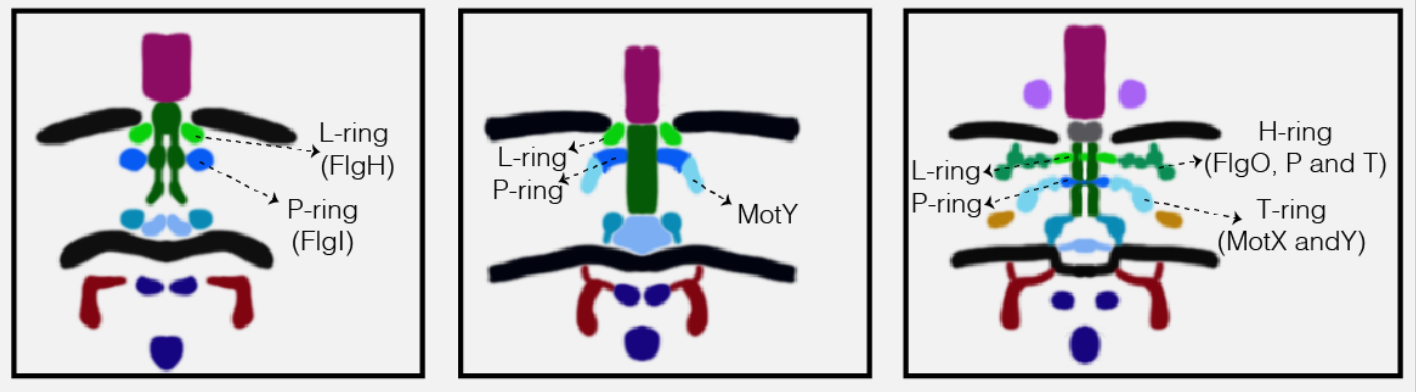

293

294

295

296

297 


\section{Figure legends}

Figure 1: The structures of three dual-stator Gammaproteobacteria flagellar motors revealed by ECT. A \& B) slices through Shewanella oneidensis MR-1 electron cryo-tomograms showing single polar flagella. C \& D) zoomed-in views of the slices shown in $\mathbf{A}$ and $\mathbf{B}$ highlighting the flagellar motors. E) central slice through a subtomogram average of the $S$. oneidensis MR-1 flagellar motor. F) schematic representation of the sub-tomogram average shown in $\mathbf{E}$ with the major parts of the motor labeled. G-L) flagellar motor of Pseudomonas aeruginosa. Panels follow the same scheme as in A-F above. M-R) flagellar motor of Legionella pneumophila. Panels follow the same scheme as above. Scale bars $50 \mathrm{~nm}$ (red) and $20 \mathrm{~nm}$ (blue and orange).

Figure 2: Compilation of all Gammaproteobacteria flagellar motors imaged to date by ECT. Central slices of sub-tomogram averages are shown for the eight Gammaproteobacteria flagellar motors revealed by ECT, including the three structures solved in this study (P. aeruginosa, L. pneumophila and S. oneidensis). The motors are classified based on their stator system: single $\mathrm{H}^{+}$-driven (dashed blue box), dual $\mathrm{H}^{+}$-driven (blue box), $\mathrm{Na}^{+}$-driven (green box) or dual $\mathrm{Na}^{+}-\mathrm{H}^{+}$-driven (green-blue box). Scale bars are $20 \mathrm{~nm}$. 
bioRxiv preprint first posted online Jul. 14,2018 ; doi: $\mathrm{http} / / \mathrm{dx}$ doi.org/10.1101/369397. The copyright holder for this preprint (which was not peer-reviewed) is the author/funder, who has granted bioRxiv a license to display the preprint in perpetuity.

\section{Supporting information:}

326

327

328

329

330

331

332

333

334

335

336

337

338

339

340

341

342

343

344

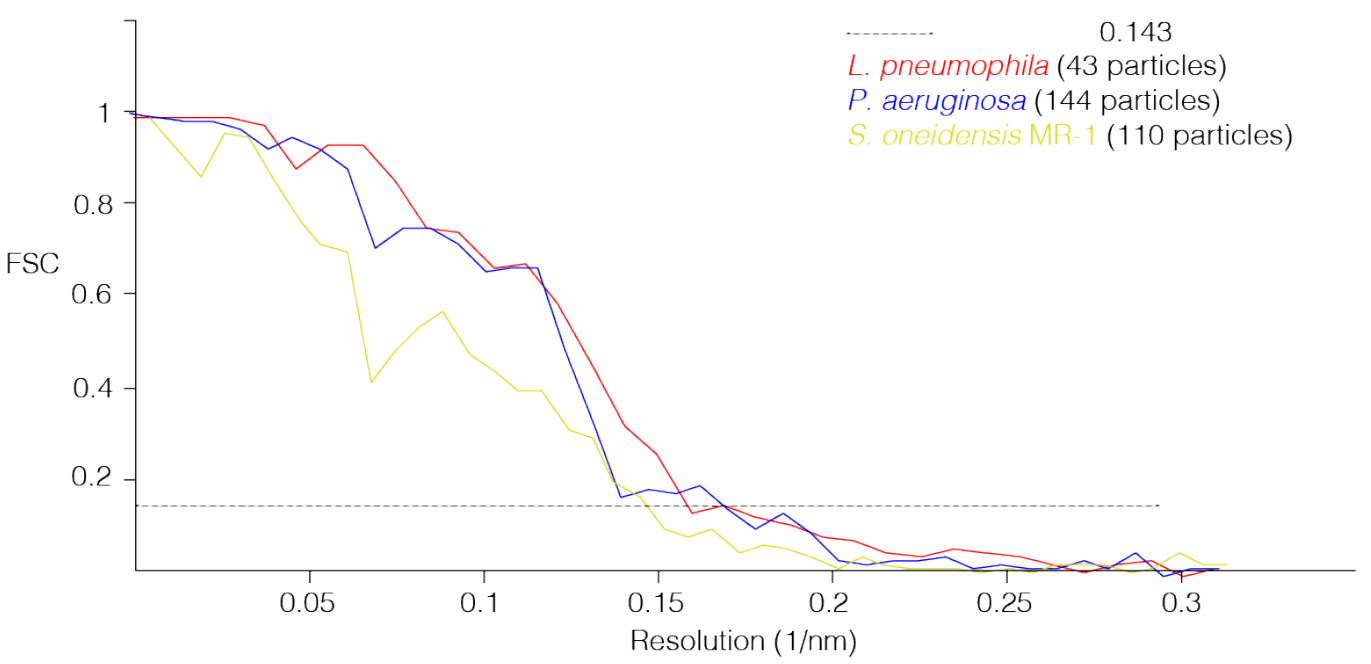

Figure S1: Gold-standard FSC curves of sub-tomogram averages. Resolutions at a 0.143 cutoff (dashed line) are: $L$. 
Table S1. Candidate homologs of H- and T-ring components in species imaged in this study.

\begin{tabular}{|c|c|c|c|c|c|}
\hline Species & $\begin{array}{c}\text { MotX } \\
\text { candidate }\end{array}$ & $\begin{array}{c}\text { MotY } \\
\text { candidate }\end{array}$ & FlgO candidate & FlgP candidate & FlgT candidate \\
\hline $\begin{array}{c}\text { Pseudomonas } \\
\text { aeruginosa } \\
\text { (dual } \mathrm{H}^{+} \text {-driven } \\
\text { stator) }\end{array}$ & - & + & - & - & - \\
\hline $\begin{array}{c}\text { Legionella } \\
\text { pneumophila } \\
\text { dual } \mathrm{H}^{+} \text {-driven } \\
\text { stator) }\end{array}$ & - & + & - & - & - \\
\hline $\begin{array}{c}\text { Shewanella } \\
\text { oneidensis } \mathrm{MR}- \\
1\end{array}$ & + & + & + & + & + \\
$\left(\begin{array}{c}\text { dual } \mathrm{Na}^{+}-\mathrm{H}^{+}- \\
\text {driven stator) }\end{array}\right.$ & & & & & \\
\hline
\end{tabular}

Table S2. Candidate homologs of $\mathrm{H}$ - and T-ring components in single $\mathrm{H}^{+}$-dependent stator systems.

\begin{tabular}{|c|c|c|c|c|c|}
\hline Species & $\begin{array}{c}\text { MotX } \\
\text { candidate }\end{array}$ & $\begin{array}{c}\text { MotY } \\
\text { candidate }\end{array}$ & FlgO candidate & FlgP candidate & FlgT candidate \\
\hline Escherichia coli & - & - & - & - & - \\
\hline $\begin{array}{c}\text { Salmonella } \\
\text { enterica }\end{array}$ & - & - & - & - & - \\
\hline $\begin{array}{c}\text { Sodalis } \\
\text { glossinidius }\end{array}$ & - & - & - & - & - \\
\hline
\end{tabular}

Table S3. Candidate homologs of $\mathrm{H}$ - and T-ring components in dual $\mathrm{H}^{+}$-dependent stator systems.

\begin{tabular}{|c|c|c|c|c|c|}
\hline Species & $\begin{array}{c}\text { MotX } \\
\text { candidate }\end{array}$ & $\begin{array}{c}\text { MotY } \\
\text { candidate }\end{array}$ & $\begin{array}{c}\text { FlgO } \\
\text { candidate }\end{array}$ & FlgP candidate & FlgT candidate \\
\hline $\begin{array}{c}\text { Azotobacter } \\
\text { vinelandii } \mathrm{DJ}\end{array}$ & - & + & - & - & - \\
\hline $\begin{array}{c}\text { Cellvibrio } \\
\text { japonicas } \\
\text { Ueda107 }\end{array}$ & - & + & - & - & - \\
\hline $\begin{array}{c}\text { Chromohalobacter } \\
\text { salexigens } \text { DSM } \\
3043\end{array}$ & - & + & + & - & - \\
\hline $\begin{array}{c}\text { Pseudomonas } \\
\text { entomophila }\end{array}$ & - & + & - & - & - \\
\hline $\begin{array}{c}\text { Saccharophagus } \\
\text { degradans 2-40 }\end{array}$ & - & + & - & - & - \\
\hline $\begin{array}{c}\text { Xanthomonas } \\
\text { campestris } \mathrm{pv.} \\
\text { campestris }\end{array}$ & - & + & - & - & - \\
\hline $\begin{array}{c}\text { Teredinibacter } \\
\text { turnerae T7901 }\end{array}$ & - & + & - & - & - \\
\hline $\begin{array}{l}\text { Pseudomonas } \\
\text { putida }\end{array}$ & - & + & - & - & - \\
\hline
\end{tabular}


Table S4. Candidate homologs of $\mathrm{H}$ - and T-ring components in $\mathrm{Na}^{+}$-dependent stator systems.

\begin{tabular}{|c|c|c|c|c|c|}
\hline Species & $\begin{array}{c}\text { MotX } \\
\text { candidate }\end{array}$ & $\begin{array}{c}\text { MotY } \\
\text { candidate }\end{array}$ & FlgO candidate & FlgP candidate & FlgT candidate \\
\hline $\begin{array}{c}\text { Colwellia } \\
\text { psychrerythraea } \\
\text { 34H }\end{array}$ & + & + & + & + & + \\
\hline $\begin{array}{c}\text { Vibrio } \\
\text { alginolyticus }\end{array}$ & + & + & + & + & + \\
\hline Vibrio fischeri & + & + & + & + & + \\
\hline
\end{tabular}

Table S5. Candidate homologs of stator system components in Colwellia psychrerythraea 34H. E-values of

BLAST results are shown for each candidate locus (name in parentheses).

\begin{tabular}{|c|c|c|c|c|}
\hline Species & MotA candidate & MotB candidate & PomA candidate & PomB candidate \\
\hline $\begin{array}{c}\text { Colwellia } \\
\text { psychrerythraea } \\
\text { 34H }\end{array}$ & $\begin{array}{c}8 \mathrm{e}-10 \\
(\mathrm{CPS}+1524)\end{array}$ & $\begin{array}{c}4 \mathrm{e}-11 \\
\left(\mathrm{CPS} \_1525\right)\end{array}$ & $\begin{array}{c}\text { 2e-124 } \\
\text { (CPS_1092) }\end{array}$ & $\begin{array}{c}4 \mathrm{e}-129 \\
\text { (CPS_1093) }\end{array}$ \\
\hline
\end{tabular}

Table S6. Raw Blast results for all species in Tables S1-S5. E-values are shown. For $E$-values exceeding the

cutoff, the top hit is listed in parentheses.

\begin{tabular}{|c|c|c|c|c|c|}
\hline Species & $\begin{array}{c}\text { MotX } \\
\text { candidate }\end{array}$ & $\begin{array}{c}\text { MotY } \\
\text { candidate }\end{array}$ & $\begin{array}{c}\text { FlgO } \\
\text { candidate }\end{array}$ & FlgP candidate & FlgT candidate \\
\hline $\begin{array}{l}\text { Azotobacter } \\
\text { vinelandii } \mathrm{DJ}\end{array}$ & $1 \mathrm{e}-06$ & $\begin{array}{c}8 \mathrm{e}-14 \\
\text { (Avin_48650) }\end{array}$ & 0.032 & 0.32 & 4.2 \\
\hline $\begin{array}{c}\text { Cellvibrio } \\
\text { japonicas } \\
\text { Ueda107 }\end{array}$ & 0.59 & $\begin{array}{c}\text { 9e-28 } \\
\text { (CJA_2588) }\end{array}$ & 0.72 & 0.29 & $6 e-09$ \\
\hline $\begin{array}{c}\text { Chromohalobacter } \\
\text { salexigens DSM } \\
3043\end{array}$ & 0.014 & $\begin{array}{c}\text { 6e-13 } \\
\text { (Csal_3309) }\end{array}$ & $\begin{array}{c}\text { 9e-16 } \\
\text { (Csal_2511) }\end{array}$ & 2.8 & 2.7 \\
\hline $\begin{array}{c}\text { Pseudomonas } \\
\text { entomophila }\end{array}$ & $3 e-05$ & $\begin{array}{c}\text { 2e-31 } \\
\text { (PSEEN1209) }\end{array}$ & 1.6 & 0.32 & 0.099 \\
\hline $\begin{array}{l}\text { Saccharophagus } \\
\text { degradans 2-40 }\end{array}$ & $6 e-06$ & $\begin{array}{c}1 \mathrm{e}-37 \\
\left(\mathrm{Sde} \_2427\right)\end{array}$ & 0.24 & 2.1 & 1.2 \\
\hline $\begin{array}{c}\text { Xanthomonas } \\
\text { campestris pv. } \\
\text { campestris }\end{array}$ & 0.019 & $\begin{array}{c}1 \mathrm{e}-13 \\
(\mathrm{XCC} 1436)\end{array}$ & 3 & 4.5 & 0.021 \\
\hline $\begin{array}{l}\text { Teredinibacter } \\
\text { turnerae T7901 }\end{array}$ & 0.7 & $\begin{array}{c}\text { 3e-35 } \\
\text { (TERTU_3000) }\end{array}$ & 1.4 & 0.061 & 1 \\
\hline $\begin{array}{l}\text { Pseudomonas } \\
\text { putida }\end{array}$ & 0.005 & $\begin{array}{c}7 \mathrm{e}-31 \\
\left(\mathrm{PP} \_1087\right)\end{array}$ & 1 & 0.77 & 0.063 \\
\hline $\begin{array}{c}\text { Legionella } \\
\text { pneumophila }\end{array}$ & $1 \mathrm{e}-08$ & $\begin{array}{c}3 \mathrm{e}-35 \\
(\operatorname{lpg} 2962)\end{array}$ & 0.87 & 0.11 & 2.2 \\
\hline
\end{tabular}


bioRxiv preprint first posted online Jul. 14,2018 ; doi: http://dx doi.org/10.1101/369397. The copyright holder for this preprint (which was not peer-reviewed) is the author/funder, who has granted bioRxiv a license to display the preprint in perpetuity.

It is made available under a CC-BY-NC-ND 4.0 International license.

\begin{tabular}{|c|c|c|c|c|c|}
\hline $\begin{array}{l}\text { Pseudomonas } \\
\text { aeruginosa }\end{array}$ & $3 e-05$ & $\begin{array}{c}2 \mathrm{e}-37 \\
(\mathrm{PA} 3526)\end{array}$ & 0.047 & 0.63 & 0.19 \\
\hline Escherichia coli & $9 e-06$ & $2 \mathrm{e}-09$ & 0.19 & 0.84 & 0.19 \\
\hline $\begin{array}{c}\text { Salmonella } \\
\text { enterica }\end{array}$ & $5 e-07$ & $5 e-09$ & 0.34 & 4.9 & 0.82 \\
\hline $\begin{array}{c}\text { Sodalis } \\
\text { glossinidius }\end{array}$ & 4.4 & $1 \mathrm{e}-07$ & 0.88 & 0.27 & 2.2 \\
\hline $\begin{array}{c}\text { Colwellia } \\
\text { psychrerythraea } \\
34 \mathrm{H}\end{array}$ & $\begin{array}{c}2 \mathrm{e}-63 \\
\left(\mathrm{CPS} \_4618\right)\end{array}$ & $\begin{array}{c}\text { 1e-73 } \\
\left(\mathrm{CPS} \_3471\right)\end{array}$ & $\begin{array}{c}2 \mathrm{e}-59 \\
\left(\mathrm{CPS} \_1469\right)\end{array}$ & $\begin{array}{c}6 \mathrm{e}-28 \\
\left(\mathrm{CPS} \_1470\right)\end{array}$ & $\begin{array}{c}5 \mathrm{e}-38 \\
\left(\mathrm{CPS} \_1468\right)\end{array}$ \\
\hline $\begin{array}{c}\text { Shewanella } \\
\text { oneidensis MR-1 }\end{array}$ & $\begin{array}{c}2 \mathrm{e}-46 \\
\left(\mathrm{SO} \_3936\right)\end{array}$ & $\begin{array}{c}2 \mathrm{e}-80 \\
\left(\mathrm{SO} \_2754\right)\end{array}$ & $\begin{array}{c}2 \mathrm{e}-19 \\
\left(\mathrm{SO} \_3257\right)\end{array}$ & $\begin{array}{c}6 \mathrm{e}-31 \\
\left(\mathrm{SO} \_3256\right)\end{array}$ & $\begin{array}{c}3 \mathrm{e}-36 \\
\left(\mathrm{SO} \_3258\right)\end{array}$ \\
\hline
\end{tabular}




\section{Materials and Methods:}

\section{Strains and growth conditions:}

Legionella pneumophila (strain Lp02) cells were grown on plates of ACES [N-(2-acetamido)-2-aminoethanesulfonic acid]-buffered charcoal yeast extract agar (CYE) or in ACES-buffered yeast extract broth (AYE) with $100 \mu \mathrm{g} / \mathrm{ml}$ thymidine. Ferric nitrate and cysteine hydrochloride were added to the media. For ECT experiments, cells were harvested in early stationary phase.

\section{7}

Shewanella oneidensis MR-1 cells belonging to the strains listed in Table S7 were used in this study. They were in a perfusion flow imaging platform. Detailed descriptions of these methods can be found in[30]. Briefly, in the chemostat method, $5 \mathrm{~mL}$ of a stationary-phase overnight LB culture was injected into a continuous flow bioreactor containing an operating liquid volume of $1 \mathrm{~L}$ of a defined medium[31], while dissolved oxygen tension (DOT) was maintained at $20 \%$. After $20 \mathrm{~h}$, and as the culture reached stationary phase, continuous flow of the defined medium[31] was started with a dilution rate of $0.05 \mathrm{~h}^{-1}$ while DOT was still maintained at $20 \%$. After $48 \mathrm{~h}$ of aerobic growth under continuous flow conditions, the DOT was manually reduced to $0 \% . \mathrm{O}_{2}$ served as the sole terminal electron acceptor throughout the experiment. $\mathrm{pH}$ was maintained at 7.0 , temperature at $30^{\circ} \mathrm{C}$, and agitation at $200 \mathrm{rpm}$. Either 24 or 40 hours after DOT reached 0\%, samples were taken from the chemostat for ECT imaging.

In the batch culture method, $200 \mu \mathrm{L}$ of an overnight LB culture of $S$. oneidensis cells was added to each of two sealed and autoclaved serum bottles containing $60 \mathrm{~mL}$ of a defined medium[31]. One of the two bottles acted as a control and was not used for imaging. To this control bottle, $5 \mu \mathrm{M}$ resazurin was added to indicate the $\mathrm{O}_{2}$ levels in resazurin in the control bottle completely faded, indicating anaerobic conditions. At this point, samples were taken for ECT imaging from the bottle that did not contain resazurin. 
London finder Quantifoil EM was glued to a $43 \mathrm{~mm} \times 50 \mathrm{~mm}$ no. 1 glass coverslip using waterproof silicone glue

(General Electric Company) and let dry for $\sim 30 \mathrm{~min}$. Using a vacuum line, the perfusion chamber (model VC-LFR-

25; C\&L Instruments) was sealed against the grid-attached glass coverslip. A total of ${ }^{\sim} 10 \mathrm{~mL}$ of the washed culture was injected into the chamber slowly to allow cells to settle on the grid surface, followed by a flow of sterile defined medium from an inverted serum bottle through a bubble trap (model 006BT-HF; Omnifit) into the perfusion chamber inlet. Subsequently, the flow of medium was stopped and the perfusion chamber was opened under sterile medium. The grid was then detached from the coverslip by scraping off the silicone glue at the grid edges using a 22-gauge needle and rinsed by transferring three times in deionized water, before imaging by ECT.

Samples were also prepared from an aerobic S. oneidensis $\mathrm{LB}$ culture grown at $30^{\circ} \mathrm{C}$ to an $\mathrm{OD}_{600}$ of $2.4-2.8$.

Pseudomonas aeruginosa PAO1 cells were first grown on LB plates at $37{ }^{\circ} \mathrm{C}$ overnight. Subsequently, cells were

Table S7. S. oneidensis strains used in this study

\begin{tabular}{|l|l|l|}
\hline Strain & Relevant genotype & Ref. \\
\hline MR-1 & Wild-type & {$[32]$} \\
\hline$\triangle p i l M N O P Q$ & type IV pili biogenesis mutant & {$[33]$} \\
\hline$\triangle m s h H I J K L M N E G B A C D O P Q$ & Msh pili biogenesis mutant & {$[33]$} \\
\hline$\triangle p i l M-Q, \triangle m s h H-Q$ & $\begin{array}{l}\text { mutant that lacks type IV and Msh } \\
\text { pili biogenesis genes }\end{array}$ & {$[33]$} \\
\hline$\triangle c r p$ & $\begin{array}{l}\text { Lacking the cAMP receptor protein } \\
\text { (CRP) }\end{array}$ & {$[34]$} \\
\hline
\end{tabular}

Sample preparation for electron cryo-tomography:

407 Cells (L. pneumophila, P. aeruginosa and S. oneidensis) from batch cultures and chemostats were mixed with BSA

408 (Bovine Serum Albumin)-treated 10-nm colloidal gold solution (Sigma-Aldrich, St. Louis, MO, USA) and $4 \mu \mathrm{L}$ of 409 this mixture was applied to a glow-discharged, carbon-coated, R2/2, 200 mesh copper Quantifoil grid (Quantifoil 410 Micro Tools) in a Vitrobot Mark IV chamber (FEI). Excess liquid was blotted off and the grid was plunge frozen in 411 a liquid ethane/propane mixture for ECT imaging. 


\section{Electron cryo-tomography:}

415 Imaging of ECT samples (S. oneidensis and P. aeruginosa) was performed on an FEI Polara 300-keV field emission 416 gun electron microscope (FEI company, Hillsboro, OR, USA) equipped with a Gatan image filter and K2 Summit 417 counting electron-detector camera (Gatan, Pleasanton, CA, USA). Data were collected using the UCSF Tomography software[35], with each tilt series ranging from $-60^{\circ}$ to $60^{\circ}$ in $1^{\circ}$ increments, an underfocus of ${ }^{\sim} 5-10 \mu \mathrm{m}$, and a cumulative electron dose of ${ }^{\sim} 130-160 \mathrm{e}^{-} / \mathrm{A}^{2}$ for each individual tilt series. For $L$. pneumophila samples, imaging was imaging filter and a K2 Summit direct electron detector in counting mode (Gatan). L. pneumophila data was also collected using UCSF Tomography software and a total dose of $\sim 100 \mathrm{e}^{-} / \mathrm{A}^{2}$ per tilt series with $\sim 6$ um underfocus.

Sub-tomogram averaging:

425 The IMOD software package was used to calculate three-dimensional reconstructions of tilt series[36]. Alternatively, 426 the images were aligned and contrast transfer function corrected using the IMOD software package before producing 427 SIRT reconstructions using the TOMO3D program[37]. Sub-tomogram averages with 2-fold symmetrization along 428 the particle $\mathrm{Y}$-axis were produced using the PEET program[38].

\section{Bioinformatics analysis:}

431 Candidate H- and T-ring component genes were identified by sequence alignment of the following Vibrio cholerae 432 proteins against the fully sequenced genomes of each bacterial species using BLASTP. The Vibrio cholerae proteins used were: MotX (Q9KNX9), MotY (Q9KT95), FlgO (Q9KQ00), FlgP (Q9KQ01) and FlgT (Q9KPZ9). Candidate stator homologs in Colwellia psychrerythraea $34 \mathrm{H}$ were identified by sequence alignment of PomAB proteins of $V$. cholerae (Q9KTL0 and Q9KTK9 respectivley) and MotAB proteins of E. coli (P09348 and P0AF06 respectively) against its genome. The C. psychrerythraea $34 \mathrm{H}$ genome contains a single flagellar motor system[23]. Candidate

437 MotX and MotY homologs identified were adjacent to the flagellar cluster in the genome, and for each stator system candidate homologs were characteristically located in tandem in the genome. The codes in parentheses represent 
bioRxiv preprint first posted online Jul. 14, 2018; doi: http://dx.doi.org/10.1101/369397. The copyright holder for this preprint (which was not peer-reviewed) is the author/funder, who has granted bioRxiv a license to display the preprint in perpetuity. It is made available under a CC-BY-NC-ND 4.0 International license.

441 